\section{Ancient ships lifted from Naples' railway tunnels}

Federica Castellani

Italian builders have stumbled on the ancient Roman port of Neapolis while digging tunnels for an underground rail system in Naples. Archaeologists have now lifted three ships dating back to the first or second centuries AD to safety, and conservators are working on how to preserve this unusual treasure.

Workers found the first of the three wooden ships in January, buried near the Piazza del Municipio. The largest, which is $\mathbf{1 3 . 5}$ metres long and weighs some 25 tonnes, was removed by crane earlier this month. All are now stored in a climate-controlled facility in Piscinola.

Researchers have long wanted to examine this ancient port. The harbour was abandoned at the end of the Roman empire, after which it gradually silted up; it had disappeared by the fourth century. This process created an airless environment which has kept the wooden ships in good condition, say researchers.

Historians expect an analysis of the wood to reveal something of the ancient climate and flora of the area. The cargo indicates how important Naples was for trade with the East. "Amazingly, the ships emerged with their entire cargo," says Daniela Giampaola, an archaeologist from Naples who is in charge of the excavation. Researchers have found ceramic containers of wine and cereals, corked glass perfume bottles and even sailors' shoe soles on the same site.

To protect the wood, conservators have encased the ships in fibreglass and filled these shells with distilled water. Chemists are testing the wood for damaging fungi and bacteria, and will then decide how best to treat it.

The ships will be kept in a room at a controlled temperature and oxygen level, under ultraviolet-filtered light.

Work on the tunnels is restarting, and researchers expect more treasures to appear as it continues.

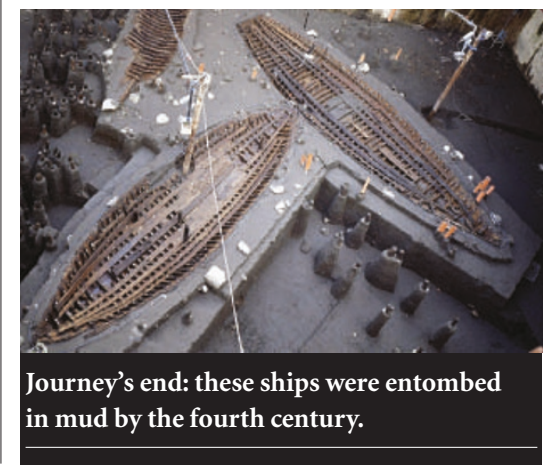

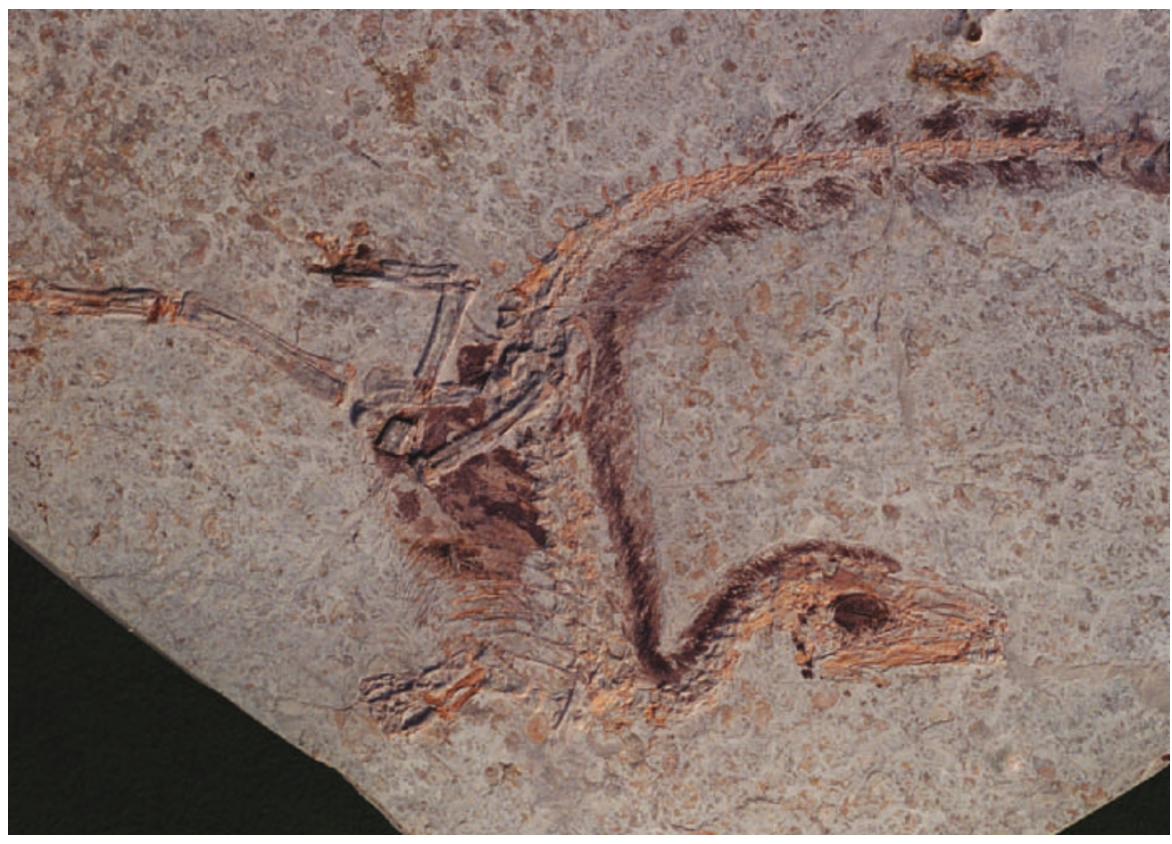

Conflict is brewing in Liaoning, where famous fossils of bird-like dinosaurs have been found.

\title{
Feathers fly as China cracks down on illegal fossil sales
}

\section{Rex Dalton, San Diego}

Officials are taking a hard line on the illicit trade in dinosaur fossils in China, leaving palaeontologists worried that valuable specimens will be lost or destroyed.

This summer, fossil-rich quarries have been blasted, some 75 people threatened with arrest, and a potentially important new specimen apparently run over with a tractor - all in conflicts over fossils that could fetch a high price on the black market.

"It is unfortunate that the monetary value of these specimens places their existence and scientific study in jeopardy," says Mark Norell, chair of the Division of Paleontology at the American Museum of Natural History in New York City, who has worked in China. The only way to deal with the current situation is "to have laws with teeth that are enforced universally and equitably," he says.

In the northeastern province of Liaoning, fossils are typically dug up by poor farmers. Their sale is illegal — particularly for specimens of high scientific value. But a trade in run-of-the-mill fossils has been tolerated.

To ensure important fossils are available for study, some Chinese scientists have developed relationships with dealers and diggers. They buy the fossils or compensate the finder in other ways.

In June, as part of the crackdown, officials at the Liaoning Bureau of Land and Resources blasted 24 deep mine shafts that had been used by farmers to find fossils. Officials say this was done to stop the fossils from being stolen. But scientists contacted by Nature, who requested anonymity for fear of jeopardizing any future work in Liaoning, describe the move as "sabotage", and say it has shut down sites that were producing quality specimens.

This summer, police scrutinized about 75 dealers and farmers; some were held briefly, charged nominal fines and then released. At the same time, informed scientists say, the provincial government has taken no action against major fossil markets, including a substantial one in the town of Chaoyang that functions openly. The scientists say that the action against the farmers may have been an attempt at extortion.

The conflict reached the attention of international dealers when a potentially exciting fossil was caught up in it. This fossil, which may represent an undescribed bird-like dinosaur, was found in July at the famous site of Sihetun during the building of a museum. Some reports say that the specimen included near-complete fossilized remnants of feathers, pressed into the rock along with the 2-metrelong skeleton after a volcanic explosion some 120 million years ago. Feather material from the Cretaceous period would be scientifically important — and would make the specimen very valuable.

Farmers are reported to have crushed the fossil with a tractor rather than give it up to officials they believed to be corrupt. Pieces are being smuggled away from the site, one source said. Chinese scientists were unable to provide more detail about the incident, but agreed that the location of a potentially exciting new specimen is now in doubt. 